Stirbu, I., Looman, C., Nijhof, G.J., Reulings, P.G., Mackenbach, J.P. Income inequalities in case death of ischemic heart disease in the Netherlands: a national record-linked study. Journal of

\begin{tabular}{|l|l|}
\hline $\begin{array}{l}\text { Postprint } \\
\text { Version }\end{array}$ & 1.0 \\
\hline Journal website & http://jech.bmi.com/content/66/12/1159.long \\
\hline Pubmed link & $\underline{\text { http://www.ncbi.nlm.nih.gov/pubmed/22685304 }}$ \\
\hline DOI & $10.1136 /$ jech-2011-200924 \\
\hline
\end{tabular}

This is a NIVEL certified Post Print, more info at http://www.nivel.eu

\title{
Income inequalities in case death of ischaemic heart disease in the Netherlands: a national record- linked study
}

\author{
IRINA STIRBu ${ }^{1,2}$, CASPAR LOOMAN ${ }^{1}$, GeEsJe J NiJHOF ${ }^{3}$, PETRA G REULINGS ${ }^{3}$, JOHAN P \\ MACKENBACH $^{1}$ \\ ${ }^{1}$ Department of Public Health, Erasmus MC, Rotterdam, The Netherlands \\ ${ }^{2}$ NIVEL, Netherlands Institute for Health Services Research, Utrecht, The Netherlands \\ ${ }^{3}$ Dutch Health care Inspectorate (IGZ), Amsterdam, The Netherlands
}

\begin{abstract}
Background Socioeconomic inequalities in ischaemic heart disease (IHD) mortality have been found in most European countries, but it is unclear to what extent inequalities in survival, as opposed to incidence, contribute to these inequalities in mortality. The author studied income-related inequalities in shortterm and long-term case death after first hospitalisation with acute myocardial infarction (AMI) and chronic ischaemic heart disease (CIHD), as well as inequalities in cardiovascular surgical procedures among patients admitted with IHD, in the Netherlands.

Methods Design: A nationwide prospective cohort study of patients first admitted for IHD. Data: Obtained by record linkage at individual level of national hospital discharge, cause of death, population and income registries. Patients: 15416 patients admitted to a hospital with first episode of AMI and 31209 patients admitted to a hospital with first episode of CIHD in the period 2003-2005. Main outcome measures: Differences by income quintile in shortterm (28 days) and long-term (1 year) case death after first hospital admission with AMI and CIHD. Differences by income quintile in Percutaneous Transluminal Coronary Angioplasty (PTCA) and Coronary Artery Bypass Graft operations among patients with first admission for AMI.

Results After adjustment for age, ethnicity and comorbidity, men and women in the lower income quintiles had a higher 28-day and 1-year case death after first hospitalisation with an AMI or CIHD. After adjustment for age and comorbidity, patients admitted to the hospital with a first AMI also had a lower probability of undergoing a PTCA procedure if they belonged to a lower income quintile. There were large between-hospital variations in inequalities in 28-day mortality for patients admitted with a first AMI.
\end{abstract}


Stirbu, I., Looman, C., Nijhof, G.J., Reulings, P.G., Mackenbach, J.P. Income inequalities in case death of ischemic heart disease in the Netherlands: a national record-linked study. Journal of Epidemiology \& Community Health: 2012, 66(12), 1159-1566

Conclusions Higher mortality from IHD among lower income people is likely to be partly due to higher case death after first hospital admission. Inequalities in utilisation of PTCA and between-hospital variations in inequalities in outcomes suggest that inequalities in access to good quality care may play a role in explaining the higher case death of IHD among people with lower socioeconomic position. Further research is needed to elucidate the causes of these inequalities in case death.

\section{BACKGROUND}

Cardiovascular diseases remain a leading cause of death in industrialised countries, but the incidence of and mortality from cardiovascular diseases, such as myocardial infarction, are not evenly distributed in the population. Since the start of the decline of ischaemic heart disease (IHD) mortality in the 1970s and 1980s, it has been observed that the timing and magnitude of the decline have been different between socioeconomic groups.1 As a result, people with a lower socioeconomic position currently experience a higher IHD mortality in most industrialised countries.2 Evidence suggests that these inequalities are partly due to inequalities in IHD incidence,3-5 which in their turn are at least partly driven by inequalities in behavioural risk factors such as smoking, excessive alcohol consumption and obesity.3,6-8

It is less clear whether inequalities in IHD mortality are also partly due to inequalities in survival after an incident event. The results of studies of short- and long-term outcomes after an incident event of IHD are inconsistent. Most studies from the USA found important socioeconomic gradients in short- and long-term mortality after hospitalisation for IHD.9-12 Canadian and European studies, however, show conflicting results: some studies found no or inconsistent and weak associations between socioeconomic status and short- and long-term mortality after hospitalisation for IHD,13-17 while other studies found a significantly higher mortality among IHD patients in lower socioeconomic groups.5,18-20 Studies which have looked at disparities in healthcare utilisation among hospitalised IHD patients have often found higher rates of utilisation of surgical and non-surgical interventions among patients with a higher socioeconomic position,21-24 which suggests that inequalities in survival after hospitalisation may be due to inequalities in access to good quality care.

The study reported here aimed to measure income-related inequalities in case death after hospitalisation for a first episode of IHD, and in use of surgical procedures during hospitalisation for IHD, in the Netherlands. In contrast to some previous studies, which used aggregate-level data on socioeconomic position (eg, neighbourhood income),12, 19,20 our study used individual-level data on socioeconomic position. While some previous studies were also conducted within a specific region or city, thanks to good facilities for nationwide record linkage our study was able to cover the Netherlands as a whole. We were also able to compare inequalities in case death after hospitalisation with inequalities in clinical incidence and general mortality of IHD, which allowed us to gauge the extent to which inequalities in case death within 28 days after an incident event may contribute to inequalities in general IHD mortality. 
Stirbu, I., Looman, C., Nijhof, G.J., Reulings, P.G., Mackenbach, J.P. Income inequalities in case death of ischemic heart disease in the Netherlands: a national record-linked study. Journal of Epidemiology \& Community Health: 2012, 66(12), 1159-1566

\section{METHODS}

\section{Data sources}

Data on hospital admissions were obtained from the Dutch National Hospital Discharge Register (HDR). Since 1986, all general and academic hospitals and most specialty hospitals have participated in this register. For each hospital admission, a new record is created in the HDR, including patient data (unique personal identifier, date of birth, gender, postal code) and hospital- and admission-specific data (type of hospital, admission date, principal and secondary diagnoses, surgical procedures). The principal diagnosis is determined at discharge and is coded using the ninth revision of the International Classification of Diseases, Clinical Modification (ICD9-CM).25 Surgical procedures are coded using the Dutch Classification of Medical Procedures, V.2.8.26

Information on income was derived from the so-called Regional Income Survey. This nationally representative register contains information extracted from the government tax service on the individual and household income of a random sample of about one-third of the Dutch population aged 15 years and older. These are officially verified income data as known to the tax service. Sampling for this register is completely independent from a person's health status or socioeconomic position, so it is unlikely that bias was introduced by this selection. For each individual enrolled in our cohort, we calculated equivalent household income. Household income was defined as the sum of the income of each individual member of the household and the income received by the household as a whole. In order to make the values comparable across families of various size and compositions, income was standardised using an equivalence scale developed at Statistics Netherlands. In this scale, one-person household is used as a reference (equivalence factor=1). Each following adult in the household adds 0.38 to the equivalence factor. Per minor child, the factor depends on age and rank of the child.27 This equivalent household income was then used to create income quintiles.

Information on the cause of death was derived from the National Cause of Death Register. Causes of death are coded using the 10th revision of the International Classification of Diseases (ICD-10).28

All three registers (National HDR, Regional Income Survey and National Cause of Death Register) were linked through the Population Register, a complete register of all inhabitants of the Netherlands that is kept up-to-date continuously. To link all these databases, we used a personal identification number that has been created and added to each database by Statistics Netherlands. This personal identifier is derived from a person's date of birth, gender and four or six digit postal code. For the entire Dutch population, approximately $85 \%$ of the combinations of date of birth, gender and postal code are unique.29

\section{Enrolment of cohort for analysis of case death and use of surgical procedures}

We used information on all hospital admissions between 1 January 2003 and 31 December 2005, and first identified all admissions for IHD. We created two groups based on the following ICD-9 codes: acute myocardial infarction (AMI, ICD-9 code 410) and chronic ischaemic heart disease (CIHD, ICD-9 code 411-414) (see figure $1)$. 
Stirbu, I., Looman, C., Nijhof, G.J., Reulings, P.G., Mackenbach, J.P. Income inequalities in case death of ischemic heart disease in the Netherlands: a national record-linked study. Journal of Epidemiology \& Community Health: 2012, 66(12), 1159-1566

\section{[FIGURE 1]}

In order to make sure that our analysis would only cover first hospitalisations for IHD, we then selected the first of the hospital admissions for IHD for the same individual in the period 2003-2005 and excluded all persons who had been admitted for IHD in the previous 5 years (1998-2002).

Next, we selected only those patients who had a unique combination of date of birth, gender and postal code in order to allow valid linkage with the population register (and, through the population register, with the income and cause of death registers). We linked our patients with the income register for the period 2002-2004 and selected only those patients for whom information on income in at least one of these 3 years was available. If information on income was available for two or three consecutive years, we used the average of these values in the analysis. In this way, we obtained a cohort of more than 46000 patients with a first hospital admission for IHD in 2003-2005 and information on income (figure 1). Patients excluded from the study due to missing income data did not differ from the patients included in the study in terms of demographic composition, mortality and case death rates.

By merging our cohort with the National Cause of Death register between 1 January 2003 and 31 December 2006, we added information on date of death (regardless of whether this occurred in or out of hospital and regardless of cause of death). This allowed us to determine case death for all patients over a period of at least 1 and at most 4 years.

The presence of comorbidity was based on discharge diagnoses of previous admissions (if any occurred in the period of 5 years preceding the index admission) and on secondary diagnoses present at the index admission. Comorbidity was classified using the Charlson index. A total of 17 conditions were assigned with a score of 1, 2 or 3 depending on the risk of dying associated with this condition. Then, the scores were summed up and given a total score between 1 and 6.30 We have no reason to believe that the recording of comorbidity is selective by income in the Netherlands.

Approval for the use of the anonymised patient data was covered by a general agreement between Statistics Netherlands and Dutch Hospital Data. No separate ethical approval was necessary for the use of these data.31 Throughout the analysis, we followed the data protection regulations of Statistics Netherlands.

\section{Data analysis}

Cox proportional hazard models were used to analyse inequalities between income quintiles in risk of death after first hospital admission for IHD. Case death in two different periods was examined: short term (from the first day of admission to 28 days after the day of admission) and long term (from the first day of admission to 1 year after the day of admission). The hazard risks were adjusted for the potential confounders age (using 5-year age groups), ethnicity (based on country of birth32) and comorbidity (using the Charlson index). Analyses were conducted for men and women separately. Results are presented as HRs with corresponding 95\% CIs. Data were analysed with SPSS software V.15.0.

In order to allow comparison with inequalities in 28-day and 1-year case death after hospital admission for a first episode of IHD, we also determined income-related inequalities in incidence of and mortality from IHD. Incidence was estimated on the 
Stirbu, I., Looman, C., Nijhof, G.J., Reulings, P.G., Mackenbach, J.P. Income inequalities in case death of ischemic heart disease in the Netherlands: a national record-linked study. Journal of Epidemiology \& Community Health: 2012, 66(12), 1159-1566

basis of the first hospital admission for IHD (as described above), and mortality was calculated for the total Dutch population, irrespective of hospital admission, on the basis of the National Cause of Death Register. We calculated rate ratios of incidence and mortality for each household income quintile using Poisson regression models in STATA software. All these models were adjusted for age (using 5-year age groups) and ethnicity.

Use of surgical procedures was analysed for patients with first admission for AMI at the index admission only (starting from the day of admission until the end of admission). There was no time limit to the follow-up for procedures related to the first admission. We estimated inequalities in Percutaneous Transluminal Coronary Angioplasty (PTCA, code 8-8370 in the Dutch Classification of Medical Procedures,26 Coronary Artery Bypass Graft Operations (CABG, code 5-36) and all surgical procedures (codes 5-35 to 5-39 and 8-830 to 8-839). PTCA is a relatively more discretionary procedure, while CABG is reserved for the more severe cases. The magnitude of inequalities was estimated using logistic regression with income as independent variable and adjusting for age, sex, ethnicity and comorbidity. In order to avoid small number problems, this analysis was done for both genders combined. Results are presented as ORs with corresponding 95\% CIs. SPSS software was used for this analysis.

We also determined whether the magnitude of income inequalities in 28-day case death varied between different hospitals. In order to do so, we conducted a multilevel analysis using the lme4-library from the statistical program R, V.10.2. Using the empirical Bayes method, we estimated the magnitude of inequalities in case death for each hospital expressed as an OR with a corresponding $\mathrm{p}$ value. This $\mathrm{p}$ value indicates whether the OR observed in a specific hospital differs statistically significantly from the average OR for all hospitals combined.

\section{RESULTS}

Numbers of patients who died within 28 days and 1 year after first admission for IHD are shown in table 1. Twenty-eight-day case death after admission for AMI varied between $14.2 \%$ for patients in the lowest income quintile and $8.3 \%$ for patients in the highest quintile. One-year case death after admission for AMI varied between $22.3 \%$ and $12.0 \%$, respectively. CIHD was less fatal; still, there were large income-related inequalities in case death, especially after 1 year. Both in AMI and CIHD, there was a clear gradient in case death by income, with a stepwise pattern of increasing risk of death with decreasing income.

\section{[TABLE 1]}

Mortality after first hospitalisation for acute myocardial infarction (AMI) and chronic ischaemic heart disease (CIHD) by income quintile and gender; the Netherlands 2003-2005

After adjustment for confounders (age, ethnicity and comorbidity), the risk of death after admission for IHD still differed between income quintiles, although statistical significance was not always reached (table 2). In the lowest income quintile, the 1year case death after first hospitalisation for AMI and CIHD was statistically significantly higher than in the highest income quintile, both for men and women. 
Stirbu, I., Looman, C., Nijhof, G.J., Reulings, P.G., Mackenbach, J.P. Income inequalities in case death of ischemic heart disease in the Netherlands: a national record-linked study. Journal of Epidemiology \& Community Health: 2012, 66(12), 1159-1566

Income-related inequalities in case death after first admission tended to become larger and more consistent with longer follow-up.

\section{[TABLE 2]}

Relative risk of dying (HRs) after first hospitalisation for acute myocardial infarction (AMI) and chronic ischaemic heart disease (CIHD) by income quintile and gender; the Netherlands 2003-2005

Three components determine inequalities in mortality from IHD in the population as a whole: inequalities in deaths among patients not admitted to the hospital, inequalities in clinical incidence and inequalities in case death after hospital admission. In figure 2, we display two of these components: income-related inequalities in clinical incidence and 28-day and 1-year case death. We compare these inequalities with inequalities in mortality from IHD in the population as a whole. Among men with the lowest income, clinical incidence of AMI was about $35 \%$ higher than among men with the highest income, and 28-day case death for AMI was 20\% higher, suggesting that both inequalities in incidence and in case death make important contributions to inequalities in mortality. For CIHD, inequalities in 1-year case death are even larger than inequalities in clinical incidence. For both AMI and CIHD, inequalities in mortality were larger than inequalities in clinical incidence and inequalities in case death. A similar picture was observed among women, although the difference between inequalities in incidence and mortality was not that large and inequalities in case death were less consistent.

\section{[FIGURE 2]}

Incidence and mortality risks for people with ischaemic heart diseases by income and gender. AMI, acute myocardial infarction (ICD-9-CM code 410); CIHD, chronic ischaemic heart disease (ICD-9-CM codes 411-414); CF, case fatality. All results are adjusted for age and ethnicity. Results for 28-day and 1-year case death are additionally adjusted for comorbidity. Relative risk for incidence and mortality; HRs for 28-day and 1-year case death.

Income-related inequalities in the use of surgical procedures in case of AMI are displayed in table 3. People with lower income underwent significantly less often PTCA procedures (RR in lowest income quintile $=0.79$ CI 0.71 to 0.89 ). A stepwise increase in the use of PTCA with increasing income can be observed. Although the lowest income group has a higher rate of CABG procedures, the difference is not statistically significant and does not compensate the lower use of PTCA as the rate for all procedures is also lower in the lowest income group (RR in lowest income quintile $=0.82(0.74$ to 0.91$)$ ).

\section{[TABLE 3]}

We also investigated whether income inequalities in 28-day case death varied by hospital. We did this only for AMI as there were not enough deaths to do a similar analysis for CIHD. We found large and significant variations between hospitals in the magnitude of income-related inequalities in 28-day case death after first admission for AMI (figure 3). Few hospitals had no or inverted income-related 
Stirbu, I., Looman, C., Nijhof, G.J., Reulings, P.G., Mackenbach, J.P. Income inequalities in case death of ischemic heart disease in the Netherlands: a national record-linked study. Journal of Epidemiology \& Community Health: 2012, 66(12), 1159-1566

inequalities in 28-day case death among their patients (left side of figure 3). Most hospitals had higher case death among patients with a lower income and in two hospitals inequalities in case death were statistically significantly larger than average inequalities for all hospitals combined. The overall test on between-hospital variations in inequalities in 28-day case death was statistically significant $(\mathrm{p}<0.001)$.

\section{[FIGURE 3]}

\section{DISCUSSION}

\section{Summary of findings}

Our study shows that income is associated with case death after first admission to a hospital with IHD in the Netherlands. These inequalities in case death are not so much smaller than inequalities in clinical incidence of IHD and thus are likely to contribute importantly to inequalities in mortality from IHD in the population as a whole. Patients admitted to the hospital with AMI had a lower probability of undergoing a PTCA procedure if they belonged to a lower income group, and there were large between-hospital variations in the magnitude of inequalities in 28-day case death after first admission for AMI.

\section{Strengths and limitations}

Our study had a number of strengths. We used national-level data and our results are representative for the total Dutch population. We were able to use an individual-level indicator of socioeconomic status. In our analysis of inequalities in case death and surgical procedures, we were able to adjust for comorbidity.

Our study also had a number of limitations. It only includes patients admitted to hospital. However, around 30\% of deaths from IHD occur before patients reach the hospital.33 Studies from other countries have shown that there is a socioeconomic gradient in out-of-hospital death as well, with higher rates of death among people with lower socioeconomic position.5,33,34 Exclusion of deaths occurring outside hospital does not bias our findings with regard to mortality among patients who have reached the hospital alive, but inequalities in pre-hospital mortality may to some extent have levelled out the differences in case severity among hospitalised patients. Inequalities in mortality among hospitalised patients may therefore underestimate inequalities in case death among all patients with incident IHD.

Our study is based on administrative data, obtained from a number of Dutch registries, that are likely to be imperfect. However, several studies have shown that for the Netherlands, the validity of hospital registration in the years 2003-2005 was adequate.35, 36 Only 3.5\% of the hospital admissions were not registered in the Dutch Hospital Registry. There is no reason to believe that this under registration is selective by income. The quality of diagnostic coding is considered to be high, judging by the number of unclear/vague diagnoses. Also, the validity of the Dutch national Cause of Death registry has been reported to be satisfactory,37 although some degree of misclassification of the cause of death is inevitable. We used income in our study as a proxy for the socioeconomic status. Income, however, might not completely reflect a person's socioeconomic position. Previous studies that used both education and income show similar magnitude of 
Stirbu, I., Looman, C., Nijhof, G.J., Reulings, P.G., Mackenbach, J.P. Income inequalities in case death of ischemic heart disease in the Netherlands: a national record-linked study. Journal of Epidemiology \& Community Health: 2012, 66(12), 1159-1566

inequalities.38 We therefore believe that our conclusions would not change using a different indicator of socioeconomic status.

We were unable to provide direct evidence for a role of medical care in generating inequalities in survival after first admission for IHD. Our evidence is largely circumstantial and consists of (1) the demonstration of inequalities in use of surgical procedures and (2) the demonstration of large between-hospital variations in the magnitude of inequalities in 28-day case death after first admission for AMI. Inequalities in case death could, however, also be due to differences between income groups in severity of the condition with which they are admitted to hospital.39,40 If lower socioeconomic groups have a more severe degree of atherosclerosis (eg, as a result of more exposure to risk factors for IHD) or reach hospital with a more advanced stage of disease (eg, as a result of delays in seeking care41), one would also expect inequalities in survival to arise. Although we controlled for comorbidity, we cannot exclude such differences in severity of disease at admission. Earlier studies, however, found that the social gradient persisted even after adjustment for left ventricular failure - the single most important predictor of survival over the short and long terms and a direct marker of myocardial damage.17 Large between-hospital variations in the outcomes of IHD pleas for the need to continuously monitor inequalities in outcomes within the healthcare system.

\section{What does this study add}

Like other studies before us, we found substantial inequalities in case death of patients who had a first hospital admission for IHD. This adds to a growing literature covering a large part of the Western world, including countries such as Sweden, Italy, UK, Canada and USA.9 13, 15, 20,42 Our results of lower use of PTCA procedure after myocardial infarction by patients with lower income are also in line with other studies from Europe and USA.21-24 Although a direct comparison with these other studies is impossible, due to differences in study design and data definitions, inequalities in survival and use of surgical procedures in the Netherlands appear to be of similar magnitude as those found in Sweden and UK.20,43, 44 This is remarkable because the Netherlands' health system is characterised by comparatively small inequalities in access by socioeconomic position, thanks to the almost complete absence of financial barriers to care.45 In international comparisons, the Netherlands has relatively small socioeconomic disparities in healthcare utilisation, with slightly higher utilisation of general practitioner care and lower utilisation of specialist care among the lower socioeconomic groups (after adjustment for health status45). In the years under study, the Netherlands changed from a mixed public-private insurance scheme to a strongly publicly regulated private insurance scheme.46 This healthcare reform did not lead to larger inequalities in the use of healthcare.47

This suggests that inequalities in utilisation of surgical procedures like PTCA in the Netherlands are unlikely to be due to financial barriers but are more likely to be related to more subtle aspects of doctor-patient interaction, such as a better level of health literacy among higher income patients or easier communication about symptoms and preferences between doctors and higher income patients.48 Previous studies have shown that behavioural factors explain an important part of socioeconomic differences in cardiovascular incidence and mortality, including incidence and mortality of AMI and CIHD.49 We were able to link our data to the 
Stirbu, I., Looman, C., Nijhof, G.J., Reulings, P.G., Mackenbach, J.P. Income inequalities in case death of ischemic heart disease in the Netherlands: a national record-linked study. Journal of Epidemiology \& Community Health: 2012, 66(12), 1159-1566

Dutch Health Survey data (POLS) and for a proportion of patients obtained data on smoking, alcohol consumption and physical activity prior to hospitalisation. The results of this analysis show that up to $76 \%$ of inequalities in incidence of cardiovascular conditions could be explained by behavioural risk factors (data reported elsewhere50). The current study shows that, however, in order to explain inequalities in mortality from AMI and CIHD, we may also need to look at carerelated factors. Although some previous studies did not find evidence for differential treatment of AMI,17 our findings suggest that further study is warranted.

\section{CONCLUSIONS}

The causes of higher mortality from IHD in lower income groups are likely to be complex. There is no doubt that behavioural factors play a role, but our study suggests that inequalities in access to good quality healthcare may also contribute to inequalities in mortality from IHD. Further study is necessary to assess whether higher case death and less surgical procedures in lower income groups indeed reflect shortcomings of the healthcare system and if so what the possible entry-points for remedial action are.

\section{What is already known on this subject}

People with a lower socioeconomic position currently experience a higher IHD mortality in most industrialised countries. Evidence suggests that these inequalities are partly due to inequalities in IHD incidence, which in their turn are at least partly driven by inequalities in behavioural risk factors such as smoking, excessive alcohol consumption and obesity. It is less clear whether inequalities in IHD mortality are also partly due to inequalities in survival after an incident event.

\section{What this study adds}

The current study shows that in order to explain inequalities in mortality from IHD, we may also need to look at care-related factors. We demonstrate that income is associated with case death after first admission to a hospital with IHD in the Netherlands. These inequalities in case death are not so much smaller than inequalities in clinical incidence of IHD and thus are likely to contribute importantly to inequalities in mortality from IHD in the population as a whole. Inequalities in utilisation of PTCA and between-hospital variations in inequalities in outcomes suggest that inequalities in access to good quality care may play a role in explaining the higher case death of IHD among people with lower socioeconomic position.

\section{FOOTNOTES}

Funding This study received financial support from the Netherlands' Health Inspectorate (Inspectie voor de Gezondheidszorg).

Competing interests None.

Provenance and peer review Not commissioned; externally peer reviewed. 
Stirbu, I., Looman, C., Nijhof, G.J., Reulings, P.G., Mackenbach, J.P. Income inequalities in case death of ischemic heart disease in the Netherlands: a national record-linked study. Journal of Epidemiology \& Community Health: 2012, 66(12), 1159-1566

\section{REFERENCES}

Davies CA, Dundas R, Leyland AH. Increasing socioeconomic inequalities in first acute myocardial infarction in Scotland, 1990-92 and 2000-02. BMC Public Health 2009;9:134.

Avendano M, Kunst AE, Huisman M, et al. Socioeconomic status and ischaemic heart disease mortality in 10 western European populations during the 1990s. Heart 2006;92:461-7.

Knoops KT, de Groot LC, Kromhout D, et al. Mediterranean diet, lifestyle factors, and 10year mortality in elderly European men and women: the HALE project. JAMA 2004;292:1433-9.

Rose KM, Suchindran CM, Foraker RE, et al. Neighborhood disparities in incident hospitalized myocardial infarction in four U.S. communities: the ARIC surveillance study. Ann Epidemiol 2009;19:867-74.

Salomaa V, Niemela M, Miettinen $\mathrm{H}$, et al. Relationship of socioeconomic status to the incidence and prehospital, 28-day, and 1-year mortality rates of acute coronary events in the FINMONICA myocardial infarction register study. Circulation 2000;101:1913-18.

Huisman M, Kunst AE, Mackenbach JP. Educational inequalities in smoking among men and women aged 16 years and older in 11 European countries. Tob Control 2005;14:10613.

Roskam AJ, Kunst AE, Van Oyen $\mathrm{H}$, et al. Comparative appraisal of educational inequalities in overweight and obesity among adults in 19 European countries. Int J Epidemiol 2010;39:392-404.

Stringhini S, Dugravot A, Shipley M, et al. Health behaviours, socioeconomic status, and mortality: further analyses of the British Whitehall II and the French GAZEL prospective cohorts. PLoS Med 2011;8:e1000419.

Rao SV, Schulman KA, Curtis LH, et al. Socioeconomic status and outcome following acute myocardial infarction in elderly patients. Arch Intern Med 2004;164:1128-33.

Wellenius GA, Mittleman MA. Disparities in myocardial infarction case fatality rates among the elderly: the 20-year Medicare experience. Am Heart J 2008;156:483-90.

Gerber Y, Weston SA, Killian JM, et al. Neighborhood income and individual education: effect on survival after myocardial infarction. Mayo Clin Proc 2008;83:663-9.

Tonne C, Schwartz J, Mittleman M, et al. Long-term survival after acute myocardial infarction is lower in more deprived neighborhoods. Circulation 2005;111:3063-70.

Picciotto S, Forastiere F, Stafoggia M, et al. Associations of area based deprivation status and individual educational attainment with incidence, treatment, and prognosis of first coronary event in Rome, Italy. J Epidemiol Community Health 2006;60:37-43.

Alter DA, Chong A, Austin PC, et al. Socioeconomic status and mortality after acute myocardial infarction. Ann Intern Med 2006;144:82-93.

Morrison C, Woodward M, Leslie W, et al. Effect of socioeconomic group on incidence of, management of, and survival after myocardial infarction and coronary death: analysis of community coronary event register. BMJ 1997;314:541-6.

Danchin N, Neumann A, Tuppin P, et al. Impact of free universal medical coverage on medical care and outcomes in low-income patients hospitalized for acute myocardial infarction: an analysis from the French national health insurance system. Circ Cardiovasc Qual Outcomes 2011;4:619-25.

Barakat K, Stevenson S, Wilkinson P, et al. Socioeconomic differentials in recurrent ischaemia and mortality after acute myocardial infarction. Heart 2001;85:390-4.

Alboni P, Amadei A, Scarfo S, et al. In industrialized nations, a low socioeconomic status represents an independent predictor of mortality in patients with acute myocardial infarction. Ital Heart J 2003;4:551-8.

Gerber Y, Benyamini Y, Goldbourt U, et al. Neighborhood socioeconomic context and longterm survival after myocardial infarction. Circulation 2010;121:375-83.

Gerward S, Tyden P, Hansen O, et al. Survival rate 28 days after hospital admission with first myocardial infarction. Inverse relationship with socio-economic circumstances. J Intern Med 2006;259:164-72. 
Stirbu, I., Looman, C., Nijhof, G.J., Reulings, P.G., Mackenbach, J.P. Income inequalities in case death of ischemic heart disease in the Netherlands: a national record-linked study. Journal of Epidemiology \& Community Health: 2012, 66(12), 1159-1566

Hetemaa T, Keskimaki I, Salomaa V, et al. Socioeconomic inequities in invasive cardiac procedures after first myocardial infarction in Finland in 1995. J Clin Epidemiol 2004;57:301-8.

Hetemaa T, Manderbacka K, Reunanen A, et al. Socioeconomic inequities in invasive cardiac procedures among patients with incident angina pectoris or myocardial infarction. Scand J Public Health 2006;34:116-23.

Ancona C, Agabiti N, Forastiere F, et al. Coronary artery bypass graft surgery: socioeconomic inequalities in access and in 30 day mortality. A population-based study in Rome, Italy. J Epidemiol Community Health 2000;54:930-5.

Korda RJ, Clements MS, Kelman CW. Universal health care no guarantee of equity: comparison of socioeconomic inequalities in the receipt of coronary procedures in patients with acute myocardial infarction and angina. BMC Public Health 2009;9:460.

CBS. Documentation Report Dutch National Hospital Discharge Register 2005 V2 [Documentatierapport Landelijke Medische Registratie (LMR) 2005V2]. 2005.

Dutch Classification of Medical Procedures, version 2.8 [Classificatie van Medisch Specialistische Verrichtingen, versie 2]. 2005.

Mackenbach JP, Kunst AE. Measuring the magnitude of socio-economic inequalities in health: an overview of available measures illustrated with two examples from Europe. Soc Sci Med 1997;44:757-71.

CBS. Documentation Report Cause of Death Registry 2005 V2 [Documentatiereport Doodsoorzakenregistratie 2005 V2]. 2005.

de Bruin A, de Bruin El, Gast A, et al. [Merging Dutch Hospital Discharge Register data and National Population Register data: methods, results and quality] Koppeling van LMR- en GBA-gegevens: methode, resultaten en kwaliteitsonderzoek. 2003.

Sundararajan V, Henderson T, Perry C, et al. New ICD-10 version of the Charlson comorbidity index predicted in-hospital mortality. J Clin Epidemiol 2004;57:1288-94.

Reitsma JB, Kardaun JW, Gevers E, et al. [Possibilities for anonymous follow-up studies of patients in Dutch national medical registrations using the Municipal Population Register: a pilot study] (In Dutch). Ned Tijdschr Geneeskd 2003;147:2286-90.

Agyemang C, Vaartjes I, Bots ML, et al. Risk of death after first admission for cardiovascular diseases by country of birth in The Netherlands: a nationwide record-linked retrospective cohort study. Heart 2009;95:747-53

Macintyre K, Stewart S, Chalmers J, et al Relation between socioeconomic deprivation and death from a first myocardial infarction in Scotland: population based analysis. BMJ 2001;322:1152-3.

Tyden P, Engstrom G, Hansen O, et al. Geographical pattern of female deaths from myocardial infarction in an urban population: fatal outcome out-of-hospital related to socioeconomic deprivation. J Intern Med 2001;250:201-7.

Paas GRA, Veenhuizen KCW. Research on the Validity of the LMR (In Dutch). Utrecht: Prismant, 2002.

Pieter DD, Kool RB, Westert GP. [Variations in Dutch National Medical Registration hardly affect the hospital standardised mortality rate (HSMR)] (In Dutch). Ned Tijdschr Geneeskd 2010;154:A2186.

Mackenbach JP, Van Duyne WM, Kelson MC. Certification and coding of two underlying causes of death in The Netherlands and other countries of the European Community. $\mathrm{J}$ Epidemiol Community Health 1987;41:156-60.

Salomaa $\mathrm{V}$, Miettinen $\mathrm{H}$, Niemela M, et al. Relation of socioeconomic position to the case fatality, prognosis and treatment of myocardial infarction events; the FINMONICA MI Register Study. J Epidemiol Community Health 2001;55:475-82.

Chan RH, Gordon NF, Chong A, et al. Influence of socioeconomic status on lifestyle behavior modifications among survivors of acute myocardial infarction. Am J Cardiol 2008;102:1583-8.

Alter DA, Iron K, Austin PC, et al. Influence of education and income on atherogenic risk factor profiles among patients hospitalized with acute myocardial infarction. Can J Cardiol 2004;20:1219-28.

Khraim FM, Carey MG. Predictors of pre-hospital delay among patients with acute myocardial infarction. Patient Educ Couns 2009;75:155-61. 
Stirbu, I., Looman, C., Nijhof, G.J., Reulings, P.G., Mackenbach, J.P. Income inequalities in case death of ischemic heart disease in the Netherlands: a national record-linked study. Journal of Epidemiology \& Community Health: 2012, 66(12), 1159-1566

Alter DA, Austin PC, Tu JV. Community factors, hospital characteristics and inter-regional outcome variations following acute myocardial infarction in Canada. Can J Cardiol 2005;21:247-55.

Rosvall M, Chaix B, Lynch J, et al

. The association between socioeconomic position, use of revascularization procedures and five-year survival after recovery from acute myocardial infarction. BMC Public Health 2008;8:44.

Davies CA, Leyland AH. Trends and inequalities in short-term acute myocardial infarction case fatality in Scotland, 1988-2004. Popul Health Metr 2010;8:33.

Stirbu I, Kunst AE, Mielck $A$, et al. Inequalities in utilisation of general practitioner and specialist services in 9 European countries. BMC Health Serv Res 2011;11:288.

Schafer W, Kroneman M, Boerma W, et al. The Netherlands: health system review. Health Syst Transit 2010;12:V-Xxvii, 1-228.

Mackenbach JP. [Diseases in the Netherlands] Ziekte in Nederland. Amsterdam: Elsevier Gezondheidszorg, 2010.

Smith SG, Wolf MS, von Wagner C. Socioeconomic status, statistical confidence, and patient-provider communication: an analysis of the Health Information National Trends Survey (HINTS 2007). J Health Commun 2010;15(Suppl 3):169-85.

Stringhini S, Sabia S, Shipley M, et al. Association of socioeconomic position with health behaviors and mortality. JAMA 2010;303:1159-66.

Stirbu I, Mackenbach JP, Nijhof G, et al. Ongelijkheid in gezondheid, is gezondheidszorg van belang? IGZ Amsterdam, 2010.

\section{TABLES AND FIGURES}

FIGURE 1:Flow chart of the cohort selection process.

\begin{tabular}{|c|c|c|}
\hline & $\begin{array}{c}\text { Acute myocardial } \\
\text { infarction }\end{array}$ & $\begin{array}{c}\text { Chronic ischemic } \\
\text { heart disease }\end{array}$ \\
\hline \multicolumn{3}{|c|}{$\begin{array}{l}\text { 1. Selection of disease-specific hospitalisations (Hospital Discharge Register } \\
\text { 2003-2005) }\end{array}$} \\
\hline N hospitalizations HDR 2003-2005 & 67889 & 213551 \\
\hline \multicolumn{3}{|c|}{$\begin{array}{l}\text { 2. Selection of the first hospital admission (Hospital Discharge Register 2003- } \\
\text { 2005) }\end{array}$} \\
\hline $\mathrm{N}$ patients with first hospital admission & 57801 & 132045 \\
\hline \multicolumn{3}{|c|}{$\begin{array}{l}\text { 3. Selection of people with no previous history of admissions for the same disease } \\
\text { (linkage with Hospital Discharge Register 1998-2002) }\end{array}$} \\
\hline $\begin{array}{l}\mathrm{N} \text { patients with first hospital admission } \\
\text { and no previous history }\end{array}$ & 55333 & 110740 \\
\hline \multicolumn{3}{|c|}{$\begin{array}{l}\text { 4. Selection of patients with unique combination of date of birth, gender and } \\
\text { postal code }\end{array}$} \\
\hline $\begin{array}{l}\mathrm{N} \text { unique patients with first hospital } \\
\text { admission and no previous history }\end{array}$ & 51458 & 101908 \\
\hline \multicolumn{3}{|c|}{$\begin{array}{l}\text { 5. Selection of patients for whom information on income was available (linkage } \\
\text { with Regional Income Survey) }\end{array}$} \\
\hline $\begin{array}{l}\mathrm{N} \text { unique patients with first hospital } \\
\text { admission and no previous history and } \\
\text { information on income }\end{array}$ & 15416 & 31209 \\
\hline
\end{tabular}

Acute myocardial infarction: ICD-9-CM code 410

Chronic ischemic heart disease: ICD-9-CM codes 411-414 
Stirbu, I., Looman, C., Nijhof, G.J., Reulings, P.G., Mackenbach, J.P. Income inequalities in case death of ischemic heart disease in the Netherlands: a national record-linked study. Journal of Epidemiology \& Community Health: 2012, 66(12), 1159-1566

Table 1: Mortality after first hospitalisation for acute myocardial infarction (AMI) and chronic ischaemic heart disease (CIHD) by income quintile and gender; the Netherlands 2003-2005

\begin{tabular}{|c|c|c|c|c|c|c|}
\hline & $\begin{array}{l}\text { Lowest } \\
\text { income }\end{array}$ & $\mid 2$ & |3 & 4 & $\begin{array}{l}\text { Highest } \\
\text { income }\end{array}$ & Total \\
\hline \multicolumn{7}{|l|}{ AMI } \\
\hline Age, mean years & 67.2 & 68.3 & 63.6 & 62.1 & 62.3 & 65.0 \\
\hline Percentage non-Dutch & 19.0 & 12.6 & 13.1 & 13.3 & 12.3 & 13.9 \\
\hline $\begin{array}{l}\text { Charlson index, mean } \\
\text { score }\end{array}$ & 0.29 & 0.28 & 0.23 & 0.18 & 0.18 & 0.24 \\
\hline $\mathrm{N}$ first hospitalisation & 2864 & 4105 & 3024 & 2751 & 2672 & 15416 \\
\hline Men & 1769 & 2631 & 2169 & 2031 & 2105 & 10705 \\
\hline Women & 1095 & 1474 & 855 & 720 & 567 & 4711 \\
\hline $\begin{array}{l}\mathrm{N}(\%) \text { died within } 28 \\
\text { days }\end{array}$ & $408(14.2)$ & $\mid \begin{array}{l}462 \\
(11.3)\end{array}$ & \begin{tabular}{|l}
306 \\
$(10.1)$
\end{tabular} & $\begin{array}{l}214 \\
(7.8)\end{array}$ & |221 (8.3) & $\begin{array}{l}1611 \\
(10.5)\end{array}$ \\
\hline $\begin{array}{l}\mathrm{N}(\%) \text { died within } 1 \\
\text { year }\end{array}$ & $638(22.3)$ & $\begin{array}{l}743 \\
(18.1)\end{array}$ & \begin{tabular}{|l}
457 \\
$(15.1)$
\end{tabular} & \begin{tabular}{|l}
305 \\
$(11.1)$
\end{tabular} & |320 (12.0) & $\begin{array}{l}2463 \\
(16.0)\end{array}$ \\
\hline $\begin{array}{l}\mathrm{N}(\%) \text { died in the full } \\
\text { follow-up period }{ }^{*}\end{array}$ & $822(28.7)$ & \begin{tabular}{|l}
991 \\
$(24.1)$
\end{tabular} & $\begin{array}{l}582 \\
(19.2)\end{array}$ & $\begin{array}{l}410 \\
(14.9)\end{array}$ & | 398 (14.9) & $\begin{array}{l}3203 \\
(20.8)\end{array}$ \\
\hline \multicolumn{7}{|l|}{ CIHD } \\
\hline Age, mean years & 64.3 & 66.5 & 62.8 & 61.3 & 61.2 & 63.5 \\
\hline Percentage non-Dutch & 20.3 & 12.7 & 14.0 & 13.2 & 12.4 & 14.3 \\
\hline $\begin{array}{l}\text { Charlson index, mean } \\
\text { score }\end{array}$ & 0.14 & 0.13 & 0.11 & 0.10 & 0.09 & 0.12 \\
\hline $\mathrm{N}$ first hospitalisation & 5314 & 8175 & 6174 & 5689 & 5857 & 31209 \\
\hline Men & 3279 & 5244 & 4225 & 4088 & 4381 & 21217 \\
\hline Women & 2035 & 2931 & 1949 & 1601 & 1476 & 9992 \\
\hline $\begin{array}{l}\mathrm{N}(\%) \text { died within } 28 \\
\text { days }\end{array}$ & 95 (1.8) & $\begin{array}{l}145 \\
(1.8)\end{array}$ & \begin{tabular}{|l}
93 \\
$(1.5)$ \\
\end{tabular} & $\begin{array}{l}59 \\
(1.0)\end{array}$ & 69 (1.2) & $\begin{array}{l}461 \\
(1.5)\end{array}$ \\
\hline $\begin{array}{l}\text { N (\%) died within } 1 \\
\text { year }\end{array}$ & ||378 (7.1) & \begin{tabular}{|l}
520 \\
$(6.4)$ \\
\end{tabular} & \begin{tabular}{|l|}
293 \\
$(4.7)$
\end{tabular} & \begin{tabular}{|l|}
211 \\
$(3.7)$
\end{tabular} & ||210 (3.6) & $\begin{array}{l}1612 \\
(5.2)\end{array}$ \\
\hline $\begin{array}{l}\mathrm{N}(\%) \text { died in the full } \\
\text { follow-up period }{ }^{*}\end{array}$ & 669 (12.6) & $\begin{array}{l}975 \\
(11.9)\end{array}$ & \begin{tabular}{|l}
504 \\
$(8.2)$ \\
\end{tabular} & \begin{tabular}{|l}
386 \\
$(6.8)$ \\
\end{tabular} & 324 (5.5) & $\begin{array}{l}2858 \\
(9.2)\end{array}$ \\
\hline
\end{tabular}

$\stackrel{\Perp}{ }{ }^{*}$ Between 1 and 4 years. 
Stirbu, I., Looman, C., Nijhof, G.J., Reulings, P.G., Mackenbach, J.P. Income inequalities in case death of ischemic heart disease in the Netherlands: a national record-linked study. Journal of Epidemiology \& Community Health: 2012, 66(12), 1159-1566

Table 2: Relative risk of dying (HRs) after first hospitalisation for acute myocardial infarction (AMI) and chronic ischaemic heart disease (CIHD) by income quintile and gender; the Netherlands 2003-2005

\begin{tabular}{|c|c|c|c|c|c|}
\hline & \multicolumn{5}{|l|}{ HR (95\% CI) } \\
\hline & Low income & 2 & || 3 & 4 & $\begin{array}{l}\text { High } \\
\text { income }\end{array}$ \\
\hline \multicolumn{6}{|l|}{ Men } \\
\hline \multicolumn{6}{|l|}{ AMI } \\
\hline death 28 -day & \begin{tabular}{|l}
$1.20(0.98$ to \\
$1.48)$
\end{tabular} & $\begin{array}{l}0.90(0.73 \text { to } \\
1.10)\end{array}$ & $\begin{array}{l}1.14(0.93 \text { to } \\
1.40)\end{array}$ & $\mid \begin{array}{l}0.97(0.77 \text { to } \\
1.21)\end{array}$ & $\mid 1$ \\
\hline $\begin{array}{l}\text { 1-year } \\
\text { death }\end{array}$ & $\begin{array}{l}1.23(1.04 \text { to } \\
1.46)\end{array}$ & $\begin{array}{l}0.98(0.83 \text { to } \\
1.15)\end{array}$ & $\begin{array}{l}1.15(0.97 \text { to } \\
1.37)\end{array}$ & $\begin{array}{l}0.96(0.79 \text { to } \\
1.16)\end{array}$ & 1 \\
\hline $\begin{array}{c}\text { Full } \\
\text { follow-up }\end{array}$ & $\begin{array}{l}1.39(1.19 \text { to } \\
1.62)\end{array}$ & $\begin{array}{l}1.12(0.97 \text { to } \\
1.30)\end{array}$ & $\begin{array}{l}1.22(1.05 \text { to } \\
1.43)\end{array}$ & $\begin{array}{l}1.03(0.87 \text { to } \\
1.22)\end{array}$ & $\mid 1$ \\
\hline \multicolumn{6}{|l|}{ CIHD } \\
\hline $\begin{array}{l}\text { 28-day } \\
\text { death }\end{array}$ & $\begin{array}{l}1.13(0.76 \text { to } \\
1.68)\end{array}$ & $\begin{array}{l}1.09(0.76 \text { to } \\
1.56) \\
\end{array}$ & $\begin{array}{l}1.11(0.75 \text { to } \\
1.64)\end{array}$ & $\begin{array}{l}0.95(0.62 \text { to } \\
1.44)\end{array}$ & 1 \\
\hline \begin{tabular}{|l} 
1-year \\
death
\end{tabular} & $\begin{array}{l}1.45(1.17 \text { to } \\
1.78)\end{array}$ & $\begin{array}{l}1.18(0.97 \text { to } \\
1.43)\end{array}$ & $\begin{array}{l}1.13(0.90 \text { to } \\
1.38)\end{array}$ & $\begin{array}{l}0.95(0.75 \text { to } \\
1.19)\end{array}$ & 1 \\
\hline $\begin{array}{c}\text { Full } \\
\text { follow-up } \\
\end{array}$ & $\begin{array}{l}1.74(1.48 \text { to } \\
2.05)\end{array}$ & $\begin{array}{l}1.48(1.27 \text { to } \\
1.72) \\
\end{array}$ & $\begin{array}{l}1.28(1.08 \text { to } \\
1.51)\end{array}$ & $\begin{array}{l}1.12(0.94 \text { to } \\
1.34)\end{array}$ & 1 \\
\hline \multicolumn{6}{|l|}{ Women } \\
\hline \multicolumn{6}{|l|}{ AMI } \\
\hline $\begin{array}{l}\text { 28-day } \\
\text { death } \\
\end{array}$ & \begin{tabular}{|l}
$1.25(0.93$ to \\
$1.68)$ \\
\end{tabular} & $\begin{array}{l}1.03(0.77 \text { to } \\
1.37) \\
\end{array}$ & $\begin{array}{l}1.13(0.82 \text { to } \\
1.56)\end{array}$ & $\begin{array}{l}0.89(0.63 \text { to } \\
1.26)\end{array}$ & 1 \\
\hline \begin{tabular}{|l} 
1-year \\
death
\end{tabular} & $\begin{array}{l}1.39(1.09 \text { to } \\
1.76)\end{array}$ & $\begin{array}{l}1.08(0.85 \text { to } \\
1.38)\end{array}$ & $\begin{array}{l}1.16(0.89 \text { to } \\
1.51)\end{array}$ & $\begin{array}{l}0.86(0.65 \text { to } \\
1.15)\end{array}$ & 1 \\
\hline $\begin{array}{c}\text { Full } \\
\text { follow-up }\end{array}$ & $\begin{array}{l}1.37(1.11 \text { to } \\
1.69)\end{array}$ & $\begin{array}{l}1.09(0.87 \text { to } \\
1.34)\end{array}$ & $\begin{array}{l}1.08(0.86 \text { to } \\
1.36)\end{array}$ & $\begin{array}{l}0.90(0.70 \text { to } \\
1.15)\end{array}$ & 1 \\
\hline \multicolumn{6}{|l|}{ CIHD } \\
\hline $\begin{array}{l}\text { 28-day } \\
\text { death } \\
\end{array}$ & \begin{tabular}{|l}
$1.01(0.60$ to \\
$1.69)$ \\
\end{tabular} & $\begin{array}{l}0.81(0.49 \text { to } \\
1.35)\end{array}$ & $\begin{array}{l}1.06(0.62 \text { to } \\
1.80)\end{array}$ & $\begin{array}{l}0.64(0.34 \text { to } \\
1.22)\end{array}$ & 1 \\
\hline \begin{tabular}{|l} 
1-year \\
death \\
\end{tabular} & \begin{tabular}{|l}
$1.42(1.05$ to \\
$1.94)$ \\
\end{tabular} & $\begin{array}{l}1.10(0.81 \text { to } \\
1.49)\end{array}$ & $\begin{array}{l}1.16(0.84 \text { to } \\
1.62)\end{array}$ & $\begin{array}{l}1.05(0.74 \text { to } \\
1.50)\end{array}$ & 1 \\
\hline $\begin{array}{c}\text { Full } \\
\text { follow-up }\end{array}$ & $\begin{array}{l}1.55(1.21 \text { to } \\
1.97)\end{array}$ & $\begin{array}{l}1.29(1.01 \text { to } \\
1.63)\end{array}$ & $\begin{array}{l}1.21(0.93 \text { to } \\
1.58)\end{array}$ & $\begin{array}{l}1.24(0.94 \text { to } \\
1.64)\end{array}$ & 1 \\
\hline
\end{tabular}

Cox proportional hazard models, adjusted for age, ethnicity and comorbidity. 
Stirbu, I., Looman, C., Nijhof, G.J., Reulings, P.G., Mackenbach, J.P. Income inequalities in case death of ischemic heart disease in the Netherlands: a national record-linked study. Journal of Epidemiology \& Community Health: 2012, 66(12), 1159-1566

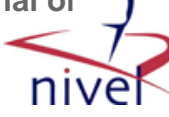

FIGURE 2: Incidence and mortality risks for people with ischaemic heart diseases by income and gender. AMI, acute myocardial infarction (ICD-9-CM code 410); CIHD, chronic ischaemic heart disease (ICD-9-CM codes 411-414); CF, case fatality. All results are adjusted for age and ethnicity. Results for 28-day and 1-year case death are additionally adjusted for comorbidity. Relative risk for incidence and mortality; HRs for 28-day and 1-year case death.
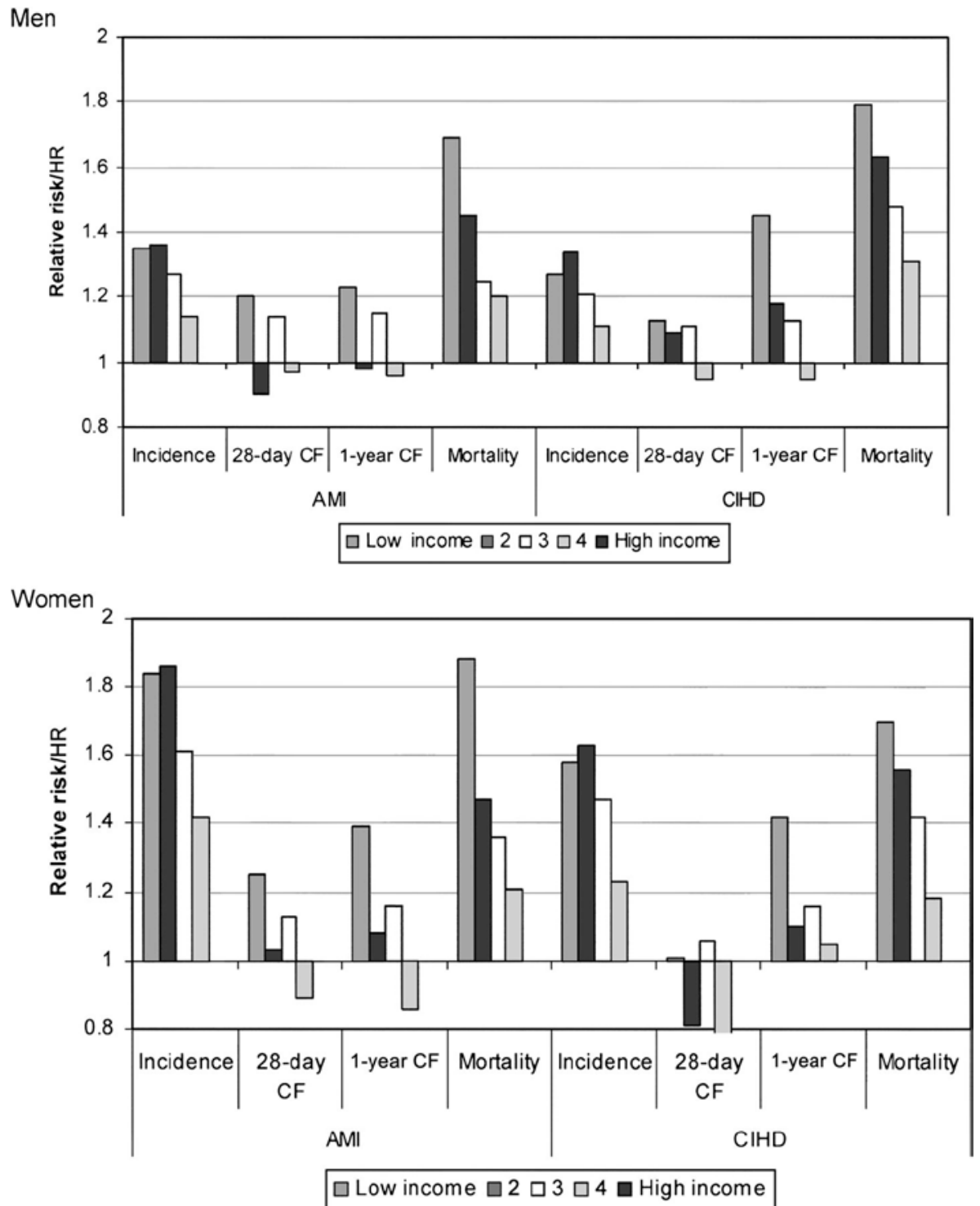
Stirbu, I., Looman, C., Nijhof, G.J., Reulings, P.G., Mackenbach, J.P. Income inequalities in case death of ischemic heart disease in the Netherlands: a national record-linked study. Journal of Epidemiology \& Community Health: 2012, 66(12), 1159-1566

Table 3: Inequalities in use of surgical procedures for patients at first hospitalisation with AMI by income; the Netherlands 2003-2005

\begin{tabular}{|c|c|c|c|c|c|}
\hline Income & Lowest income & 2 & 3 & 4 & $\begin{array}{l}\text { Highest } \\
\text { income }\end{array}$ \\
\hline \multicolumn{6}{|l|}{ PTCA } \\
\hline $\mathrm{N}$ & 533 & 808 & 711 & 710 & 709 \\
\hline OR & $\begin{array}{l}0.79(0.71 \text { to } \\
0.89)\end{array}$ & $\begin{array}{l}0.87(0.79 \text { to } \\
0.96)\end{array}$ & $\begin{array}{l}0.90(0.81 \text { to } \\
0.99)\end{array}$ & $\begin{array}{l}0.96(0.87 \text { to } \\
1.05)\end{array}$ & $\| 1$ \\
\hline \multicolumn{6}{|c|}{ CABG } \\
\hline \begin{tabular}{|l|}
$\mathrm{N}$ \\
\end{tabular} & 39 & 39 & 40 & 32 & 31 \\
\hline OR & $\begin{array}{l}1.45(0.86 \text { to } \\
2.45)\end{array}$ & $\begin{array}{l}0.99(0.62 \text { to } \\
1.59)\end{array}$ & $\begin{array}{l}1.18(0.73 \text { to } \\
1.89)\end{array}$ & $\begin{array}{l}1.08(0.69 \text { to } \\
1.68)\end{array}$ & $\mid 1$ \\
\hline \multicolumn{6}{|c|}{ All procedures } \\
\hline \begin{tabular}{|l|}
$\mathrm{N}$ \\
\end{tabular} & 606 & 895 & 786 & 764 & 764 \\
\hline OR & $\begin{array}{l}0.82(0.74 \text { to } \\
0.91)\end{array}$ & $\begin{array}{l}0.85(0.77 \text { to } \\
0.94)\end{array}$ & $\begin{array}{l}0.92(0.83 \text { to } \\
1.02)\end{array}$ & $\begin{array}{l}0.96(0.87 \text { to } \\
1.07)\end{array}$ & $\mid 1$ \\
\hline
\end{tabular}

Adjustment by age, gender, ethnicity and comorbidity. PTCA, Percutaneous Transluminal Coronary Angioplasty: code 8-8370. CABG, Coronary Artery Bypass Graft, code 5-36. All procedures: codes 5-35 to 5-39 and 8-830 to 8-839 in the Dutch Classification of Medical Procedures.26

AMI, acute myocardial infarction (ICD-9-CM code 410). 
Stirbu, I., Looman, C., Nijhof, G.J., Reulings, P.G., Mackenbach, J.P. Income inequalities in case death of ischemic heart disease in the Netherlands: a national record-linked study. Journal of Epidemiology \& Community Health: 2012, 66(12), 1159-1566

Figure 3: Income inequalities in the risk of 28-day case death after first hospitalisation with AMI, by hospital; the Netherlands 2003-2005. AMI, acute myocardial infarction (ICD-9-CM code 410). Adjustment by age, gender, ethnicity and comorbity. Hospitals \#2 and \#\# 96 and 97 had inequalities in 28-case death statistically significantly larger than average inequalities for all hospitals combined $(\mathrm{OR}=1.24)$. The overall test on between-hospital variations in inequalities in 28-day case death was statistically significant $(\mathrm{p}<0.001)$.

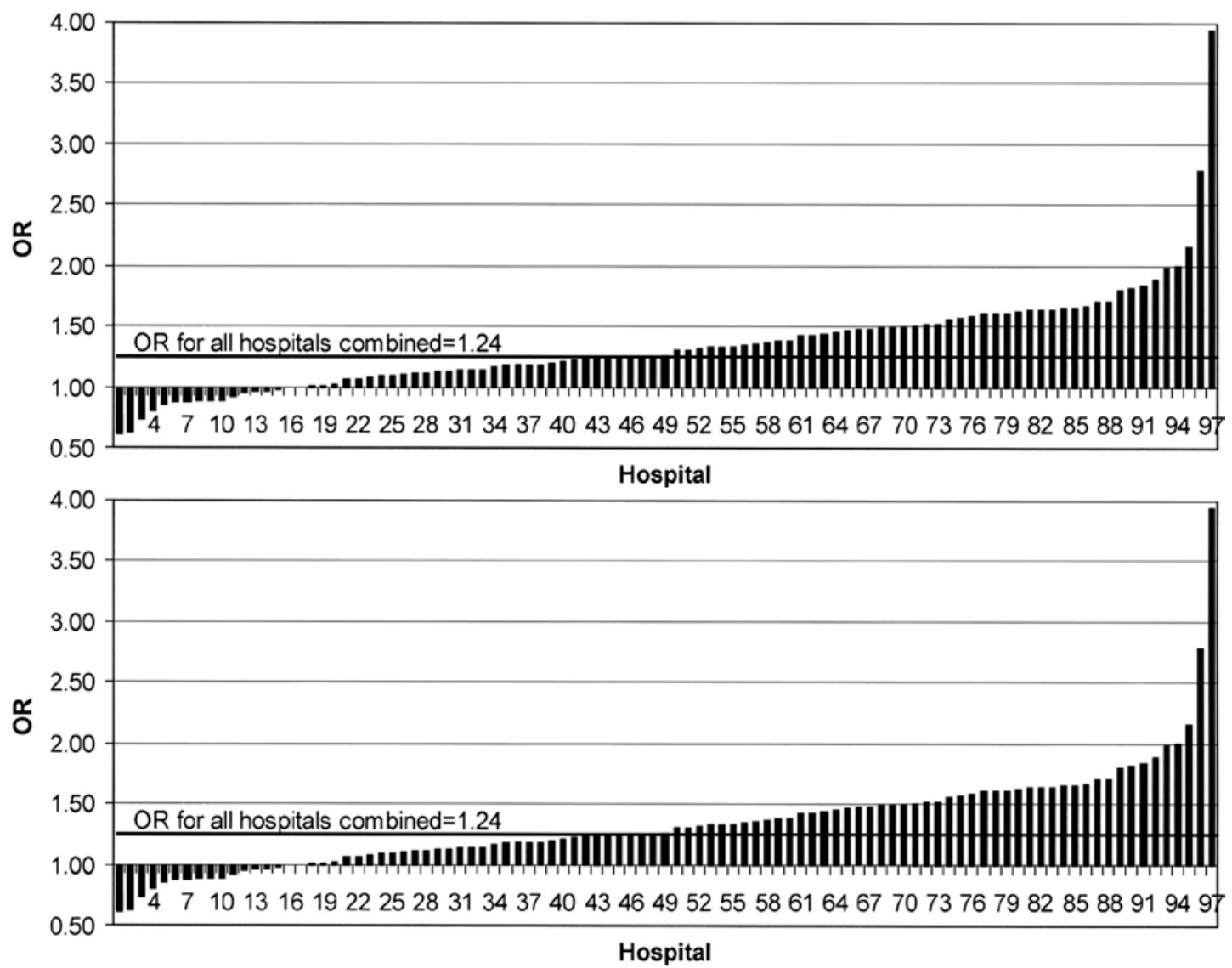

